\title{
E-WOM (Electronic Word Of Mouth): Dimensi dan Pengaruhnya Terhadap Keputusan Berkunjung Wisatawan ke Gili Matra di Kabupaten Lombok Utara (KLU)
}

\author{
Didy Ika Supryadi, Himawan Sutanto. \\ Universitas Mataram
}

\begin{tabular}{l}
\hline A R T ICLE I N F O \\
\hline Keywords : \\
EWoM, Tourist Decisions, \\
Multiple Regression \\
Analysis, Gili Matra North \\
Lombok Regency (KLU)
\end{tabular}

Received : 27 Juli 2018; Accepted: 26 Agustus 2018; Published: September 2018

ABSTRACT : This research is entitled "E-Wom (Electronic Word Of Mouth): Dimensions and Effects on Tourist Decisions of Travelers to Gili Matra in North Lombok Regency (KLU)". The formulation of the problem in this study is the dimensions of Electronic Word of Mouth (EWOM) consisting of Concern for Others, Expressing Positive Feeling, Economic Incentives, Helping the Company, Platform Assistance influencing Tourist Visit Decisions on Gili Matra on Facebook, Instagram and media other online. The purpose of this research is to find out the influence of the dimensions of Electronic Word of Mouth (EWOM) consisting of Concern for Others, Expressing Positive Feeling, Economic Incentives, Helping the Company, Platform Assistance on Decisions of Visiting Travelers on Gili Matra on Facebook, Instagram and other online media. . The data used in this study are primary data, namely data originating from respondents and secondary data, namely data from the North Lombok Regency Culture and Tourism Office. The research variables used are 1. Variable Electronic Word Of Mouth $(X)$. In this study, the independent variables determined were Electronic Word Of Mouth (e-WOM) consisting of five dimensions, namely: Concern for others, Expressing positive feelings, Economic Insentive, Helping the Company, Platform assistance. Decision Visiting Variables (Y). In this study, the dependent variable determined is the visiting decision of tourists which includes information and recommendations received by tourists through Facebook, Instagram and other online media related to 3 Gili Matra social media accounts. The data analysis technique used in this study is multiple linear regression. The results of the study show that the E-WOM Dimension has a positive and significant influence on Tourist Visiting Decisions to Gili Matra, North Lombok Regency (KLU)

Kata Kunci :

EWoM, Keputusan

Berkunjung Wisatawan, Analisis Regresi Berganda, Gili Matra Kabupaten Lombok Utara (KLU)
ABSTRAK : Penelitian ini berjudul "E-Wom (Electronic Word Of Mouth): Dimensi dan Pengaruhnya Terhadap Keputusan Berkunjung Wisatawan ke Gili Matra di Kabupaten Lombok Utara (KLU)". Rumusan masalah dalam penelitian ini adalah Apakah dimensi Electronic Word of Mouth (EWOM) yang terdiri dari Concern for Others, Expressing Positive Feeling, Economic Incentives, Helping the Company, Platform Assistance mempengaruhi Keputusan Berkunjung Wisatawan pada Gili Matra di media sosial Facebook, Instagram dan media online lainnya. Tujuan penelitian ini adalahmengetahui pengaruh dimensi Electronic Word of Mouth (EWOM) yang terdiri dari Concern for Others, Expressing Positive Feeling, Economic Incentives, Helping the Company, Platform Assistance pada Keputusan Berkunjung Wisatawan pada Gili Matra di media sosial Facebook, Instagram dan media online lainnya. Data yang digunakan dalam penelitian ini adalah data primer yaitu data yang berasal dari responden dan data sekunder yaitu data yang berasal dari Dinas Kebudayaan dan Pariwisata Kabupaten Lombok Utara. Variabel penelitian yang digunakan adalah 1. Variabel Electronic Word of Mouth (X). Dalam penelitian ini variabel bebas yang ditetapkan adalah Electronic Word Of Mouth (e-WOM) yang terdiri dari lima dimensi yaitu: Concern for others, Expressing positive feelings, Economic Insentive, Helping the Company, Platform assistance.2. Variabel Keputusan Berkunjung Wisatawan (Y). Dalam penelitian ini variabel terikat yang ditetapkan adalah keputusan berkunjung wisatawan yang meliputi informasi dan rekomendasi yang diterima wisatawan melalui akun media sosial Facebook, Instagram dan media online lainnya yang terkait dengan 3 Gili Matra. 
70| Didy Ika Supryadi, Himawan Sutanto/E-WOM:Dimensi dan Pengaruhnya....

Teknik analisa data yang digunakan dalam penelitian ini adalah regresi linier berganda. Hasil Penelitian menunjukkan bahwa Dimensi E-WOM memiliki pengaruh yang positif dan signifikan terhadap Keputusan Berkunjung Wisatawan ke Gili Matra, Kabupaten Lombok Utara (KLU)

Corresponding Author:

Alamat : Program Studi Ekonomi Pembangunan, Fakultas Ekonomi dan Bisnis, Universitas Mataram, Jln. Majapahit No. 62 Mataram.

e-mail: didyika@unram.ac.id

2018, EKONOBIS All right reserved 


\section{PENDAHULUAN}

\section{Latar Belakang}

Abad ke 21 adalah era kemajuan teknologi Industri perdagangan elektronik atau e-commerce yang terus tumbuh dan berkembang di Indonesia, dapat diyakini sebagai bagian penting dari pertumbuhan ekonomi. Tawaran produk dan jasa atas layanan online yang menarik, mudah, kreatif dan tepat, juga menjadi faktor percepatan pertumbuhan transaksi ecommerce di Indonesia.

Inilah kesempatan para pengusaha nasional untuk memanfaatkan penguasaan pasar dan karakteristiknya yang dapat menjadi peluang emas dengan memberikan tawaran produk dan jasa layanan yang tepat dan sesuai dengan keinginan. Kehadiran E-commerce bagi dunia pariwisata dalam meningkatkan pendapatan pariwisata sangatlah penting. Pengoptimalan potensi pariwisata tidak hanya berada dalam pembenahan lokasi ataupun atraksi wisata, namun juga harus diikuti dengan pemanfaatan teknologi internet dalam melakukan promosi serta pemesanan langsung oleh wisatawan. Kepariwisataan Indonesia pada dasarnya memiliki potensi yang sangat besar dan merupakan sektor yang dapat diandalkan untuk mengembangkan, dengan syarat pengembangan potensi ini didukung oleh pola perencanaan dan pengembangan yang menyeluruh dengan melibatkan pemanfaatan teknologi internet.

Namun perkembangan kepariwisataan ini harus didukung oleh pola pengelolaan internet dalam rangka menyediakan informasi yang menyeluruh bagi wisatawan, yang nantinya dapat dipakai sebagai alat pengambilan keputusan untuk melakukan perjalanan wisata. Pengambilan keputusan untuk melakukan perjalanan wisata sifatnya lebih kompleks dibandingkan untuk pengambilan keputusan untuk membeli barang mewah. Faktor vital yang menjadi dasar pengambilan keputusan wisatawan berkunjung adalah produk wisata.
Wisatawan akan mencari informasi bagaimana produk wisata dalam suatu destinasi, dalam berbagai sudut dan informasi yang dibutuhkan.

Rendahnya pengelolaan produk wisata dalam suatu destinasi akan menjadi sangat berpengaruh bagi wisatawan mengunjungi tempat wisata. Mulai dari kurangnya pengelolaan atraksi wisata yang dimiliki suatu destinasi, kurangnya pelayanan yang diberikan kepada wisatawan atau kurang sigapnya pengelola dalam menanggapi komplain pengunjung wisata, Menurut Suswantoro (2007:48), indikator atribut produk wisata terdiri dari atraksi wisata, amenitas, dan aksebilitas. Ketiga aspek tersebut harus dapat dikemas sedemikian rupa sehingga dapat menjadi lebih menarik dan memberikan kenyamanan bagi calon wisatawan (Muljadi. 2012:89)

Selain produk wisata salah satu faktor yang menjadi peran penting dalam memasarkan suatu objek wisata agar seseorang melakukan kunjungan wisata adalah Word of Mouth. Pengaruh interpersonal dan WOM merupakan sumber informasi utama karena sifat produk pariwisata yang itangible sulit dievaluasi sebelum dikonsumsi (Litvin et all, 2006:1). Namun, perkembangan internet yang semakin pesat menjadikan Word of Mouth (WOM) mengalami modernisasi sebagai electronic Word of Mouth (e-WOM).e-WOM adalah pernyataan positif dan negatif yang dibuat oleh pelanggan potensial, aktual, atau mantan pelanggan mengenai sebuah produk atau perusahaan yang dibuat tersedia untuk banyak orang dan lembaga melalui internet (Hennig-Thurau et al, 2004 dalam Chen dan Wu, 2012).

Word Tourism Organizations mengungkapkan bahwa sekitar 95\% pengguna web menggunakan internet untuk mengumpulkan informasi berkaitan dengan pariwisata dan $93 \%$ mengunjungi 
website pariwisata ketika sedang merencakan liburan. Sementara itu, jumlah orang yang beralih menggunakan internet untuk merencanakan liburan telah meningkat lebih $300 \%$ selama lima tahun terakhir (Di Virgilio dan Di Pietro, 2013:9).

Oleh karena itu, internet dapat dijadikan sebagai sarana komunikasi akibat adanya ulasan maupun komentar yang ditulis oleh netizen. Ulasan mengenai destinasi maupun obyek wisata secara khusus akan mengurangi beban kognitif dan resiko yang digunakan selama proses pengambilan keputusan serta mendukung traveler untuk membuat pilihan yang lebih baik (Pantano et al, 2011 dalam Di Virgilio dan Di Pietro, 2013).

Kawasan Wisata Gili Matra yang terletak di Kabupaten Lombok Utara memiliki tiga gugusan pulau-pulau kecil, yaitu Gili Air, Gili Meno dan Gili Trawangan. Gili dalam bahasa Sasak berarti pulau.Penamaan Gili Matra merupakan singkatan dari ketiga pulau tersebut (Meno, Air dan Trawangan). Dalam Dinas Pariwisata kawasan ini juga dikenal dengan nama singkatan lain yaitu Gili Matra (Trawangan, Meno dan Air).Kawasan Tiga Gili Lombok kini dikenal sebagai salah satu destinasi paling banyak dituju wisatawan. Faktanya, wisatawan domestik dan mancanegara selalu membanjiri kawasan tersebut. Derasnya arus wisatawan yang berkunjung ke kawasan Tiga Gili, tidak hanya terjadi pada akhir pekan, musim libur sekolah, melainkan setiap hari. Berikut adalah sajian data jumlah kunjungan wisatawan di kawasan Tiga Gili.

Tabel 1. Kunjungan Wisatawan di Tiga Gili Kabupaten Lombok Utara (KLU) s/d April 2017 Berdasarkan Tamu Menginap

\begin{tabular}{|l|c|l|c|c|}
\hline Bulan & Trawangan & Meno & Air & Total \\
\hline Januari & 2.533 & 1.193 & 1.383 & 5.109 \\
\hline Februari & 10.440 & 1.159 & 1.439 & 2.598 \\
\hline Maret & 11.265 & 1.397 & 866 & 13.528 \\
\hline April & 10.613 & 1.364 & 943 & 12.920 \\
\hline Total & 34.851 & 5.113 & 4.631 & 34.155 \\
\hline
\end{tabular}

Sumber : Dinas Kebudayaan dan Pariwisata KLU, 2017

Dari Tabel 1.1 jumlah kunjungan wisatawan di tiga gili dari bulan Januari sampai dengan bulan Maret 2017 terlihat adanya kenaikan, kecuali pada bulan April 2017. Kenaikan jumlah pengunjung juga diikuti dengan tercapainya target kunjungan wisatawan di kawasan tiga gili.

Kawasan Wisata Gili Matra ini menjadi obyek wisata bahari yang sangat digemari dan terkenal di dunia internet baik oleh wisatawan mancanegara maupun domestik.Informasi wisatanya dapat diakses dengan bebas dan mendalam berasal dari situs resmi maupun tidak resmi.Meskipun Pemerintah Daerah Kabupaten Lombok
Utara memiliki situs resmi, namun keberadaan media sosial, blog, microblogging, social networking sites tidak dapat dibantah memiliki peranan penting dalam penyebarluasan informasi mengenai kawasan Gili Matra. Selain itu, situs non pemerintah lainnya seperti tripadvisor menjadi salah satu media yang popular bagi wisatawan dalam proses pencarian informasi yang berkaitan dengan pariwisata di Gili Matra. Wisatawan dapat dengan leluasa bertukar informasi, memberikan opini, berkomentar seputar perjalanan maupun memberi tanggapan dalam sebuah topik di dalam forum seperti tripadvisor sehingga menciptakan 
komunikasi interaktif antar wisatawan terkait pariwisata di Gili Matra. Proses seperti ini disebut sebagai WOM yang diterapkan melalui media elektronik (Elektronic Word of Mouth). EWOM yang terjadi mengenai Gili Matra pada dasarnya bervariasi, karena EWOM tersebut berasal dari ide dan pengalaman wisatawan yang berbeda pada saat berkunjung ke Gili Matra.Oleh karena itu, perlu diketahui faktor EWOM yang bagaimana yang berkontribusi dalam membentuk EWOM dan bagaimana pengaruhnya terhadap keputusan berkunjung wisatawan. Berdasarkan latar belakang tersebut, maka perlu dilakukan suatu penelitan mengenai " $E$-Wom (Electronic Word Of Mouth): Dimensi dan Pengaruhnya Terhadap Keputusan Berkunjung Wisatawan ke 3 Gili di Kabupaten Lombok Utara (KLU)".

\section{Rumusan Masalah}

Berdasarkan uraian diatas, maka permasalahan yang diteliti dalam penelitian ini adalah Apakah dimensi Electronic Word of Mouth (EWOM) yang terdiri dari Concern for Others, Expressing Positive Feeling, Economic Incentives, Helping the Company, Platform Assistance mempengaruhi Keputusan Berkunjung Wisatawan pada 3 Gili Matra di media sosial Facebook, Instagram dan media online lainnya

\section{Tujuan Penelitian}

Tujuan penelitian ini adalah untuk mengetahui pengaruh dimensi Electronic Word of Mouth (EWOM) yang terdiri dari Concern for Others, Expressing Positive Feeling, Economic Incentives, Helping the Company, Platform Assistance pada Keputusan Berkunjung Wisatawan pada 3 Gili Matradi media sosial Facebook, Instagram dan media online lainnya

\section{Manfaat Penelitian}

Adapun manfaat penelitian ini adalah :

1. Membantu Dinas Pariwisata Kabupaten Lombok Utara dalam meningkatkan kunjungan wisatawan ke Kabupaten Lombok Utara

2. Membantu Pemerintah Kabupaten Lombok Utara dalam mengembangkan pariwisata di Kabupaten Lombok Utara

3. Secara teoritis sebagai tambahan referensi bagi pihak-pihak yang ingin melakukan penelitian lebih lanjut berkaitan dengan dimensi EWOM terhadap kunjungan wisatawan di 3 Gili Matra Kabupaten Lombok Utara

\section{TINJAUAN PUSTAKA}

\section{Penelitian Terdahulu}

Vina Ivana, Adelia Sari dan Sienny Thio (2014)melakukan Penelitian yang berjudul Electronic Word-of-Mouth (eWOM) dan Pengaruhnya terhadap Keputusan Pembelian di Restoran dan Kafe di Surabaya. e-WOM telah menjadi fenomena yang sedang berkembang seturut dengan meningkatnya penggunaan situs jejaring sosial. Elemen-elemen yang terdapat pada eWOM turut berperan dalam keputusan pembelian yang dilakukan oleh konsumen di restoran dan kafe di Surabaya.Teknik analisa yang digunakan dalam penelitian ini adalah kuantitatif kausal dengan metode regresi linier berganda. Hasil Penelitian menemukan bahwa variabel-variabel (intensity, valence of opinion, dan content) $\mathrm{e}-$ WOM memiliki pengaruh yang positif dan signifikan terhadap keputusan pembelian.

Yurdianti (2017) melakukan penelitian yang berjudul Pengaruh E-Wom (Electronic Word Of Mouth) Dan Citra Destinasi (Destination Image) Terhadap Keputusan Kunjungan Wisata Pantai Gandoriah Kota Pariaman. Penelitian ini bertujuan untuk menguji pengaruh EWOM (Electronic Word Of Mouth) dan citra destinasi (destination image) terhadap keputusan kunjungan wisata Pantai Gandoriah kota Pariaman. 
Sampel penelitian ini adalah sebanyak 160 responden dengan populasi masyarakat umum yang tidak berdomisili di kota Pariaman dan wisatawan yang berkunjung ke kewasan Pantai Gandoriah dengan menggunakan metode accidental sampling dan purposive sampling. Pengujianhipotesis dilakukan dengan analisis $R$-Square dan uji T-statistic menggunakan program SPSS (Statistical Programfor Social Science). Hasil penelitian menunjukkan bahwa E-WOM (Electronic Word of Mouth) berpengaruh signifikan terhadap keputusan kunjungan wisata Pantai Gandoriah dan citra destinasi (destination image) tidak berpengaruh signifikan terhadap keputusan kunjungan wisata Pantai Gandoriah. Nidienna Singgih Ardiyanto \& Dr. Hari Susanta N, M.Si (2017) melakukan penelitian yang berjudul Pengaruh Produk Wisata Dan Electronic Word Of Mouth Terhadap Keputusan Berkunjung (Studi pada Pengunjung Objek Wisata Pantai Bondo Jepara), Penelitian ini bertujuan untuk mengetahui pengaruh Produk Wisata, dan Electronic Word of Mouth terhadap Keputusan Berkunjung di Objek Wisata Pantai Bondo. Tipe penelitian ini adalah eksplanatory research, di mana teknik pengumpulan data yang digunakan yaitu dengan alat bantu kuesioner, Sampel yang dipilih berjumlah 100 orang dengan teknik pengambilan accidental sampling dan purposive sampling. Responden tersebut adalah pengunjung Objek Wisata Pantai Bondo yang sudah pernah berkunjung ke Pantai Bondo. Analisis data yang digunakan uji validitas, uji reliabilitas, koefisien korelasi, koefisien determinasi, regresi linier sederhana, regresi linier berganda, dan uji signifikansi (uji $t$ dan F) dengan SPSS. Berdasarkan hasil analisis diketahui bahwa variabel Produk Wisata memberikan kontribusi pengaruh terhadap Keputusan Berkunjung sebesar 36\%. Variabel Electronic Word of Mouth memberikan kontribusi pengaruh terhadap Keputusan Berkunjung sebesar $45,1 \%$ Sedangkan, Secara simultan Produk Wisata dan Electronic Word of Mouth memberikan kontribusi pengaruh terhadap Keputusan Berkunjung sebesar 53\%. Artinya, semakin baik Produk Wisata dan Electronic Word of Mouth maka semakin tinggi Keputusan Berkunjung di Objek Wisata Pantai Bondo.

DianWahyuUtami\& Marheni Eka Saputri, ST,. MBA (2016) melakukan penelitian yang berjudul Pengaruh Electronic Word of Mouth (EWom)TerhadapKeputusanPembelianpa da Konsumen Café Roti Gempol Dan Kopi Anjis Bandung.Penelitian ini bertujuan untuk melihat seberapa besar pengaruh electronic word of mouth terhadap keputusan pembelian pada Cafe Roti Gempol dan Kopi Anjis Bandung. Penelitian ini merupakan penelitian kuantitatif dengan analisis data deskriptif dan kausal, responden yang diteliti dalam penelitian ini berjumlah 100 orang yang telah melakukan pembelianpada Café Roti Gempoldan Kopi Anjis Bandung yang diperoleh dengan menggunakan teknik non- probability sampling. Kemudian dilakukan analisis terhadap data yang diperoleh dengan menggunakan analisis linear sederhana. Hasilpenelitian menunjukan bahwaelectronic word of mouth berada pada posisi angka 72,03\% dengan kategori tinggi, Keputusan Pembelian berada pada posisi $77,85 \%$ dengan kategori tinggi. Berdasarkan hasil uji hipotesis secarake seluruhan electronic word of mouth secara parsial berpengaruh signifikan terhadap keputusan pembelian padaCafé Roti Gempol dan Kopi Anjis. Hal ini dibuktikan dengan nilai thitung $>$ ttabel, yaitu 9,297>1,984. Berdasarkan koefisien determinasi electronic word of mouth berpengaruh sebesar 46,92\% terhadap keputusan pembelian. 
Tabel 2 Rangkuman Penelitian Terdahulu

\begin{tabular}{|c|c|c|c|c|}
\hline $\begin{array}{c}\text { PENULIS \& } \\
\text { TAHUN }\end{array}$ & JUDUL & $\begin{array}{c}\text { TUJUAN } \\
\text { PENELITIAN }\end{array}$ & $\begin{array}{c}\text { METODE } \\
\text { PENELITIAN }\end{array}$ & KESIMPULAN \\
\hline $\begin{array}{l}\text { Vina Ivana, Adelia } \\
\text { Sari dan Sienny } \\
\text { Thio (2014) }\end{array}$ & $\begin{array}{l}\text { Electronic } \\
\text { Word-of- } \\
\text { Mouth (e- } \\
\text { WOM) dan } \\
\text { Pengaruhnya } \\
\text { terhadap } \\
\text { Keputusan } \\
\text { Pembelian di } \\
\text { Restoran dan } \\
\text { Kafe di } \\
\text { Surabaya }\end{array}$ & $\begin{array}{l}\text { mengetahui } \\
\text { Electronic } \\
\text { Word-of- } \\
\text { Mouth (e- } \\
\text { WOM) dan } \\
\text { Pengaruhny } \\
\text { a terhadap } \\
\text { Keputusan } \\
\text { Pembelian } \\
\text { di Restoran } \\
\text { dan Kafe di } \\
\text { Surabaya }\end{array}$ & $\begin{array}{l}\text { Regresi } \\
\text { linier } \\
\text { berganda }\end{array}$ & $\begin{array}{l}\text { Variabel-variabel (intensity, } \\
\text { valence of } \\
\text { opinion, dan content) e- } \\
\text { WOM memiliki pengaruh } \\
\text { yang positif dan signifikan } \\
\text { terhadap keputusan } \\
\text { pembelian }\end{array}$ \\
\hline Yurdianti (2017) & $\begin{array}{l}\text { Pengaruh E- } \\
\text { Wom } \\
\text { (Electronic } \\
\text { Word Of } \\
\text { Mouth) Dan } \\
\text { Citra Destinasi } \\
\text { (Destination } \\
\text { Image) } \\
\text { Terhadap } \\
\text { Keputusan } \\
\text { Kunjungan } \\
\text { Wisata Pantai } \\
\text { Gandoriah } \\
\text { Kota Pariaman }\end{array}$ & $\begin{array}{l}\text { menguji } \\
\text { pengaruh E- } \\
\text { WOM } \\
\text { (Electronic } \\
\text { Word Of } \\
\text { Mouth) dan } \\
\text { citra } \\
\text { destinasi } \\
\text { (destination } \\
\text { image) } \\
\text { terhadap } \\
\text { keputusan } \\
\text { kunjungan } \\
\text { wisata } \\
\text { Pantai } \\
\text { Gandoriah } \\
\text { kota } \\
\text { Pariaman }\end{array}$ & $\begin{array}{l}\text { Accidental } \\
\text { sampling } \\
\text { dan } \\
\text { purposive } \\
\text { sampling }\end{array}$ & $\begin{array}{l}\text { E-WOM (Electronic Word } \\
\text { Of Mouth) berpengaruh } \\
\text { signifikan terhadap } \\
\text { keputusan kunjungan } \\
\text { wisata Pantai Gandoriah } \\
\text { dan citra destinasi } \\
\text { (destination image) tidak } \\
\text { berpengaruh signifikan } \\
\text { terhadap keputusan } \\
\text { kunjungan wisata Pantai } \\
\text { Gandoriah. }\end{array}$ \\
\hline $\begin{array}{l}\text { Nidienna Singgih } \\
\text { Ardiyanto \& Dr. } \\
\text { Hari Susanta N, } \\
\text { M.Si (2017) }\end{array}$ & $\begin{array}{l}\text { Pengaruh } \\
\text { Produk Wisata } \\
\text { Dan Electronic } \\
\text { Word Of } \\
\text { Mouth } \\
\text { Terhadap } \\
\text { Keputusan } \\
\text { Berkunjung } \\
\text { (Studi pada } \\
\text { Pengunjung } \\
\text { Objek Wisata } \\
\text { Pantai Bondo } \\
\text { Jepara) }\end{array}$ & $\begin{array}{l}\text { mengetahui } \\
\text { pengaruh } \\
\text { Produk } \\
\text { Wisata, dan } \\
\text { Electronic } \\
\text { Word of } \\
\text { Mouth } \\
\text { terhadap } \\
\text { Keputusan } \\
\text { Berkunjung } \\
\text { di Objek } \\
\text { Wisata } \\
\text { Pantai } \\
\text { Bondo }\end{array}$ & $\begin{array}{l}\text { Eksplanator } \\
\text { y research }\end{array}$ & 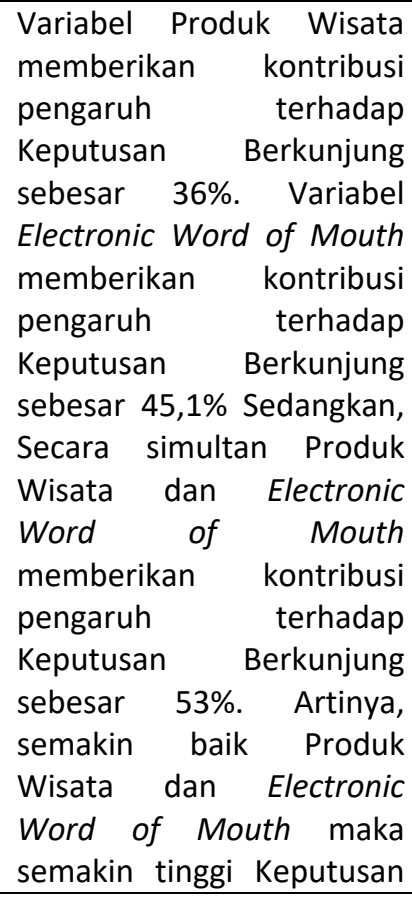 \\
\hline
\end{tabular}




\begin{tabular}{|c|c|c|c|c|}
\hline & & & & $\begin{array}{l}\text { Berkunjung di Objek } \\
\text { Wisata Pantai Bondo. }\end{array}$ \\
\hline $\begin{array}{l}\text { DianWahyuUtami } \\
\text { \& Marheni Eka } \\
\text { Saputri, ST,. MBA } \\
\text { (2016) }\end{array}$ & $\begin{array}{l}\text { Pengaruh } \\
\text { Electronic } \\
\text { Word Of } \\
\text { Mouth (E- } \\
\text { Wom)Terhada } \\
\text { p Keputusan } \\
\text { Pembelian } \\
\text { pada } \\
\text { Konsumen } \\
\text { Café Roti } \\
\text { Gempol Dan } \\
\text { Kopi Anjis } \\
\text { Bandung }\end{array}$ & $\begin{array}{l}\text { untuk } \\
\text { melihat } \\
\text { seberapa } \\
\text { besar } \\
\text { pengaruh } \\
\text { electronic } \\
\text { word of } \\
\text { mouth } \\
\text { terhadap } \\
\text { keputusan } \\
\text { pembelian } \\
\text { pada Cafe } \\
\text { Roti Gempol } \\
\text { dan Kopi } \\
\text { Anjis } \\
\text { Bandung }\end{array}$ & $\begin{array}{l}\text { Analisis } \\
\text { linear } \\
\text { sederhana }\end{array}$ & $\begin{array}{l}\text { Electronic word of mouth } \\
\text { berada pada posisi angka } \\
72,03 \% \text { dengan kategori } \\
\text { tinggi, } \\
\text { KeputusanPembelianberad } \\
\text { a pada posisi } 77,85 \% \\
\text { dengan kategori tinggi. } \\
\text { Berdasarkan hasil uji } \\
\text { hipotesis secara } \\
\text { keseluruhan electronic } \\
\text { word of mouth secara } \\
\text { parsial berpengaruh } \\
\text { signifikan terhadap } \\
\text { keputusan pembelian pada } \\
\text { Café Roti Gempoldan Kopi } \\
\text { Anjis. Hal ini dibuktikan } \\
\text { dengan nilai thitung> } \\
\text { ttabel, yaitu 9,297>1,984. }\end{array}$ \\
\hline
\end{tabular}

Sumber : diolah dari berbagai sumber penelitian

\section{Landasan Teori}

\section{1 .Wisatawan}

The International Union of Official Travel Organization dalam Billy Castyana (2013) menggunakan batasan mengenai pengunjung-setiap orang yang datang kesuatu negara atau tempat tinggal lain dan biasanya dengan maksud apapun kecuali untuk pekerjaan yang menerima upahsecara umum, yaitu :

a. Wisatawan (Tourist) : seorang atau kelompok orang yang melakukan suatu perjalanan wisata, jika lama tinggalnyasekurang-kurangnya 24 jam di daerah atau negara yang dikunjunginya;

b. Pelancong (Excursionist): : seorang atau kelompok orang yang melakukan suatu perjalanan wisata, jika lama tinggalnya kurang dari 24 jam.

c. Traveler, yaitu orang yang melakukan perjalanan antar dua atau lebih lokalitas d. Visitor, yaitu orang yang melakukan perjalanan ke daerah yang bukan merupakan tempat tinggalnya, kurang dari 12 bulan, dan tujuan perjalanannya bukanlah untuk terlibat dalam kegiatan untuk mencari nafkah, pendapatan, atau pengidupan di tempat tujuan.

e. Tourist, yaitu bagian dari visitor yang menghabiskan waktu paling tidak satu malam (24 jam) di daerah yang dikunjungi.

\section{EWoM (electronic word-of-mouth)}

Menurut Richins dan Root-Shafer dalam Viranti Mustika Sari (2012) WoM adalah proses penyampaian informasi dari orang ke oarang dan memainkan peran utama dalam keputusan pembelian pelanggan dalam Twitter Power: Tweets as Electronic Word of Mouth. Selain itu, dalam jurnal tersebut juga dijelaskan bahwa dalam situasi komersial, WoM melibatkan pelanggan untuk berbagi sikap, opini, atau reaksi tentang bisnis, produk, atau jasa dengan 
orang lain. WoM positif juga dianggap sebagai media komunikasi pemasaran yang kuat bagi perusahaan untuk mempengaruhi pelanggan. Fungsi WoM berdasarkan socisl networking dan Trust, orang mengandalkan keluarga, teman dan orang lain dalam jaringan sosialnya.

Eaton dalam Susilo Hadi (2013), dalam pemasaran melalui online atau ecommerce bentuk-bentuk word-ofmouth diistilahkan dengan e-word-ofmouth atau praktisi Online WoM menyebutnya dengan electronic word of mouth, sedangkan beberapa artikel populer menyebutnya dengan istilah "word-of-mouse"marketing. eWoM menurut Kevin, Dwayne dan Gremler dalam Susilo Hadi (2013) adalah pernyataan positif atau negatif oleh potensial, aktual atau former konsumen mengenai suatu produk atau perusahaan dan disebarkan kepada orang lain atau perusahaan lain melalui internet.

$$
\text { Menurut Arwiedya dalam }
$$

Marza Riyandika Nugraha (2013) dalam media promosi yang berpengaruh terhadap keputusan pembelian salah satunya ialah online word of mouth dengan mengatakan bahwa word of mouth adalah komunikasi interpersonal antara dua bahkan lebih individu seperti anggota kelompok referensi atau konsumen dan tenaga penjual dimana semua orang mempunyai pengaruh atas pembelian terus menerus melalui suatu komunikasi sedangkan Word of Mouth online adalah proses word of mouth dengan menggukan media internet atau web. Jadi dengan aktivitas dalam eWoM menurut Park dan Kirn dalam Marza Riyandika Nugraha (2013) konsumen akan mendapatkantingkat transparansi pasar yang tinggi, dengan kata lain konsumen memiliki peran aktif yang lebih tinggi dalam siklus value chain sehingga mampu mempengaruhi produkdan harga berdasarkan preferensiindividu.

Dalam pemasaran eWoM memberikan beberapa keuntungan, menurut Susilo Hadi (2013 : 6) : Keuntungan eWoM adalah costeffective dan karena kedinamisannya konten komunikasi dapat diubah sesering dan secepat kebutuhan pemasar. Selain itu, keuntungan besar eWoM lainnya adalah sifatnya yang multiple objectivers dimana eWoM mampu membawa fungsi peningkatan awareness dan motibate direct purchasesekaligus.

Salah satu media eWoM yang biasa digunakan perusahaan adalah media sosial. Ali Hasan (2014) menyebut social media marketing is the practice of facilitating a dialogue, using various online platform including blogs, professional and social network, video and photo sharing, wikis, forums and related web technologies untuk memanfaatkan para pecinta merek atau perusahaan untuk mempromosikan diri merekamelaluiberbagaisosialmedia.S osial media marketing adalah sebuah kolaborasi massal, orkestra publik di dunia maya, yang pada hakekatnya saling memberi dan menerima informasi.

\section{DimensiEWOM}

Penelitian Eunha Jeonga dan Soo Cheong Jang dalam Viranti Mustika Sari (2012) yang berfokus pada eWoM positif terhadap restoran, mendeskripsikan bahwa dimensi eWoM positif direfleksikan melalui dimensi berikut ini :

a. Concern forOthers

Concern for others (kepedulian terhadap orang lain). Menurut Hennig- Thurau dkk, kepedulian terhadap orang lain berkaitan erat dengan konsepaltruisme. Misalnya mencegah orang lain membeli 
produk yang buruk atau jasa yang dapat menjadi altruistic. Kepedulian terhadap orang lain adalah motif yang sangat penting dalam industry restoran karena intangibility produk restoran menuntut pelanggan mengandalkan WoM atau eWoM karena keinginan murni mereka membantu pelanggan restoran lain dengan berbagi pengalaman positif konsumen. Concern for other dalam kontek pariwisata adalah consumer dimana pengelola atau semua staf perusahaan pariwisata menunjukkan keinginan tulus untuk membantu teman atau saudara membuat lebih baik keputusan membeli.

b. Expressing Positive Feelings

Menurut Sundaram, berbeda dengan motif untuk mengekspresikan perasaan negatif, mengekspresikan perasaan positif ini dipicu oleh pengalaman konsumsi positif. Pengalaman positif pelanggan restoran memberikan kontribusi untuk ketegangan psikologis dalam pelanggan karena mereka memiliki keinginan yang kuat untuk berbagi sukacita dari pengalaman orang lain. Ketegangan ini dapat diberitahukan dengan mengartikulasikan sebuah pengalaman yang positif.

c. Helping the Company

Latar belakang pada motivasi ini sama dengan motif kepedulian terhadap orang lain, altruisme atau keinginantulus untukmembantuoranglain.Satusatunya perbedaan antara membantu perusahaan dan kepedulian terhadap orang lain adalah objek. Dalam penelitian Hennig Thurau, pelanggan restoran termotivasi untuk terlibat dalam eWoM karena untuk memberikan sesuatu perusahaan dengan imbalan untuk pengalaman positif bersantap mereka.Helping the company adalah hasil dari kepuasan konsumen dengan produk dan keinginan berikutnya untuk membantu perusahaan.Pelanggan dimotivasi untuk terlibat dalam komunikasi eWoM untuk memberikan perusahaan "sesuatu sebagai imbalan" berdasarkan pengalaman yang baik. Efek yang dimaksud dari kegiatan komunikatif ini adalah bahwaperusahaan akan menjadi atau tetap sukses. Mendukung perusahaan ini terkait dengan motif altruisme umum dan mengacu pada latar belakang psikologis yang sama dengan kekhawatiran motif pertama concern for others. Menurut penafsiran ini, konsumen menganggap perusahaan lembaga sosial yang layak mendapatkan dukunganan (dalam bentuk komunikasi eWoM).Selain itu, motif ini juga dapat didukung oleh teori ekuitas.Teori ekuitas menunjukan bahwa orang menginginkan pertukaran yang equitable dan fair.Jika konsumen merasa ia telah menerima rasio output/ input lebih tinggi darip erusahaan, kemudian membantu perusahaan dengan merekomendasikan penawarannya melalui internet adalah dalah satu cara rasio output/ input dapat menyamakan kedudukan.

\section{d. PlatformAssistance}

Pengoperasionalisasikan perilaku eWoM dapat diliberdasarkan dua cara : (1) frekuensi kunjungan konsumen pada opinion platform dan (2) jumlah komentar ditulis oleh konsumen pada opinion platform.

e. Venting NegativeFeelings

Untuk mencegah orang lain mengalami masalah yang mereka miliki. Upaya ini biasanya terdapat pada eWoM negative, yaitu jika pelanggan mengalami hal yang tidakmenyenangkan atau negative 
bagi mereka. Berbagipengalaman konsumsi negatif melalui publikasi komentar online dapat membantu konsumen untuk mengurangi ketidakpuasan terkait denganemosi negatif mereka.

f. Extraversion/positiveself

enhancement

Motif ini mencakup fokus pada manfaat psikologis komunikator dari eWoM mengintegrasikan kategori motif asli untuk mengekspresikan perasaan positif, peningkatan diri.

g. Social Benefits

Afiliasi dengan sebuah komunitas virtual dapat mewakili suatu manfaat sosial bagi konsumen untuk alas an identifikasi dan integrasi sosial, dengan demikian, dapat diduga bahwa konsumen terlibat dalam komunikasi eWoM untuk berpartisipasi dan menjadi milik komunitas online. Secara khusus, konsumen dapat menulis komentar pada opinion platform, perilaku tersebut menandakan partisipasi mereka dalam dan kehadiran dengan komunitas virtual pengguna platform dan memungkinkan mereka menerima manfaat sosial dari keanggotaan komunitas.

h. Economiclncentives

Manfaat ekonomi telah ditunjuk sebagai pendorong penting dari perilaku manusia secara umum dan dianggap oleh penerima sebagai tanda penghargaan terhadap perilaku resipien oleh pemberi hadiah. Dengan demikian penerimaan penghargaan ekonomi untuk komunikasi eWoM dari operator platform adalah bentuk lain dari utilitas penerimaan.

i. AdviseSeeking

Dalam konteks berbasis web opinionplatform, konsumsi terjadiketika individu membaca ulasan produk dan komentar yang ditulis oleh orang lain, yang juga dapat memotivasi konsumen untuk menulis komentar.
Secara khusus, peneliti berharap bahwa konsumen dapat mengartikulasikan komentar secara online, menggambarkan pengalaman mereka dengan produk dan meminta konsumen lain untuk menyerahkan pemecahan masalah informasi. Menulis dan / atau meminta informasi tentang konsumen, onlineopinion platform memungkinkan kontributor untuk mendapatkan umpan balik yang lebih spesifik dan berguna daripada hanya membaca komentar secaraanonim. Dalam penelitian ini peneliti menggunakan lima dimensi yaitu Concern for others, Expressing positive feeling, Economic incentives, Helping the companydan Platform assistance

\section{Keputusan Pembelian}

Keputusan pembelian merupakan hal yang lazim di pertimbangkan konsumen dalam proses pemenuhan kebutuhan akan barang maupun jasa. Pada kebanyakan orang, perilaku pembelian konsumen seringkali diawali dan dipengaruhi oleh banyaknya rangsangan (simuli) dari luar dirinya, baik berupa rangsangan pemasaran maupun rangsangan dari lingkungan yang lain. Menurut Ali Hasan (2013) proses pengambilan keputusan pembelian berlangsung secara runtut dalam lima tahap, akan tetapi tidak semua konsumen melewati semua tahapan ini ketika mereka membuat keputusan untuk membeli, karena pada kenyataannya beberapa tahap dapat dilewati tergantung jenis pembelian. Kelima tahap tersebut adalah : pengenalan masalah, mencari informasi, evaluasi alternatif, keputusan pembelian dan evaluasi purna beli.

\section{Jenis Penelitian}

METODE PENELITIAN

Jenis penelitian yang dilakukan adalah penelitian Deskriptif Verifikatif.Menurut 
(Arikunto 2010:03), penelitian Deskriptif adalah penelitian yang bertujuan untuk menyelidiki keadaan, kondisi atau halhal yang lain yang sudah disebutkan, yang hasilnya dipaparkan dalam bentuk laporan penelitian. Penelitian Deskriptif dilakukan untuk memperoleh gambaran atau penelitian tentang ciri-ciri variabel Electronic Word of Mouth terhadap keputusan pembelian.Penelitian Verifikatif bertujuan untuk mengetahui hubungan kausalitas antara variabel melalui suatu pengujian hipotesis (Arikunto 2010:15).

\section{Objek Penelitian}

Penelitian ini menganalisa tentang pengaruh Electronic Word of Mouth (eWOM) terhadap keputusan pembelian pada media sosial Facebook, Instagram dan media online lainnya pada 3 Gili (Gili Trawangan, Gili Meno, Gili Air). Objek yang menjadi variabel bebas atau independent variable adalah $(\mathrm{X})$ yaitu dimensi Electronic Word of Mouth (eWOM), kemudian, variabel terikat atau Dependen Variable (Y) adalah keputusan kunjungan wisatawan pada 3 Gili. Pelaksanaan penelitian ini berlangsung di wilayah 3 Gili, Kecamatan Pemenang, Kabupaten Lombok Utara dan objek penelitian yang dijadikan populasi dalam penelitian ini adalah konsumen yang menggunakan media sosial Facebook, Instagram dan media online lainnya.

\section{Populasi danSampel}

Populasi adalah semua obyek atau subyek yang diteliti dalam penelitian. Populasi yang diteliti dalam penelitian ini adalah konsumen yang menggunakan media sosial Facebook, Instagram dan media online lainnya sebagai referensi untuk mengunjungi 3 Gili di Kecamatan Pemenang, Kabupaten Lombok Utara yang jumlahnya tidak diketahui secara pasti.

Sampel adalah bagian dari populasi yang diteliti (Arikunto, 2010:112).Sampel adalah bagian dari populasi yang diambil melalui cara-cara tertentu yang memiliki karakteristik tertentu, jelas dan lengkap yang dianggap dapat mewakili populasi.

Metode yang digunakan dalam pengambilan sampel adalah metode non- probability sampling dengan teknik Purposive Judgement Sampling yaitu sampel yang dipilih dengan cermat sehingga relevan dengan rancangan penelitian. Teknik ini merupakan teknik pemilihan sampel berdasarkan ciri-ciri khusus yang dimiliki sampel tersebut yang dipertimbangkan memiliki hubungan yang sangat erat dengan ciriciri responden atau konsumen yang melakukan kunjungan ke3 Gili Matra yang mendapatkan informasi atau rekomendasi melalui media sosial Facebook, Instagram dan media online lainnya.

Hair (2010:112), menyarankan bahwa jumlah sampel penelitian yang tidak diketahui jumlah populasi pastinya, minimal berjumlah lima kali variabel yang dianalisa atau indikator pertanyaan. Jumlah pertanyaan dari penelitian ini berjumlah 25, maka diperoleh hasil perhitungan sampel sebagai berikut:

Jumlah Sampel $=5 \times 24=125$ sampel

Berdasarkan uraian di atas, maka jumlah responden yang dalam penelitian ini berjumlah 125 responden yang dapat mewakili konsumen yang menggunakan media sosial Facebook, Instagram dan media online lainnyasebagai referensi untuk mengunjungi 3 Gili di Kecamatan Pemenang, Kabupaten Lombok Utara. Sampel dengan karakteristik demografi seperti jenis kelamin, usia, pekerjaan yang telah ditentukan adalah sampel yang telah atau pernah melakukan kunjungan di 3 Gili, Kecamatan Pemenang, Kabupaten Lombok Utara.

\section{Data dan Sumber Data}

Data yang dipakai dalam penelitian ini diperoleh dari sumber yang secara garis besar dapat dikelompokkan menjadi dua yaitu: 
1. Data Primer

Data Primer yaitu data asli yang dikumpulkan sendiri oleh peneliti untuk menjawab masalah penelitiannya secara khusus.Umumnya data primer ini sebelumnya belum tersedia, sehingga seorang peneliti harus melakukan pengumpulan sendiri data ini berdasarkan kebutuhannya (Istijanto dalam Sunyoto, 2012:27).

2. DataSekunder

Data Sekunder yaitu data yang bersumber dari catatan yang ada pada perusahaan dan dari sumber lainnya yaitu dengan mengadakan studi kepustakaan dengan mempelajari buku-buku atau literatur yang ada hubungannya dengan objek penelitian (Sunyoto, 2012:41).

\section{Teknik Pengumpulan Data}

Teknik pengumpulan data yang digunakan dalam penelitian ini dapat dijelaskan sebagai berikut :

1. Kuesioner, Yaitu metode pengumpulan data dengan cara menggunakan daftar pertanyaan yang diajukan kepada responden untuk dijawab dengan memberikan angket. Pada umumnya isi materi kuesioner meliputi identitas responden dan butir-butir pertanyaan variabel penelitian beserta alternatif jawaban (Sunyoto, 2011:142).

2. Dokumentasi, Pengumpulan data melalui dokumentasi bertujuan untuk mengetahui konsep-konsep yang berkaitan dengan penelitian. Data ini juga diperoleh dari berbagai jurnal, arsip, sumber dokumen lain.

\section{Skala Pengukuran}

Menurut Sugiyono (2010:93), skala pengukuran merupakan kesepakatan yang digunakan sebagai acuan untuk menentukan panjang pendeknya interval yang ada dalam alat ukur, sehingga alat ukur tersebut bila digunakan dalam pengukuran akan menghasilkan data kuantitatif.

Skala pengukuran yang digunakan dalam penelitian ini adalah skala likert.Skala Likert adalah teknik skala non-komparatif dan unidimensional yaitu hanya mengukur sifat tunggal.Rensis Likert mengasumsikan sikap dapat diukur dan intensitas suatu pengalaman adalah linear yaitu duduk di sebuah kontinum dari sangat setuju sampai sangat tidak setuju.

Responden diminta untuk memberikan tanggapan dengan skala ini terhadap setiap pertanyaan dengan memilih satu dari lima jawaban yang tersedia berdasarkan perasaan mereka menggunakan skala ordinal.

Pemberian skor pada skala ini dari angka 1 sampai dengan 5 dengan perincian sebagai berikut:

\begin{tabular}{|l|l|l|}
\hline 1. Sangat Setuju (SS) & $=$ & 5 \\
\hline 2. Setuju (S) & $=$ & 4 \\
\hline 3. Netral (N) & $=$ & 3 \\
\hline 4. Tidak Setuju (TS) & $=$ & 2 \\
\hline 5. Sangat Tidak Setuju (STS) & $=$ & 1 \\
\hline
\end{tabular}

\section{Variabel Penelitian}

1.Variabel Electronic Word Of Mouth (X) Dalam penelitian ini variabel bebas yang ditetapkan adalah Electronic Word Of Mouth (e-WOM) yang terdiri dari lima dimensi yaitu: Concern for others, Expressing positive feelings, Economic Insentive, Helping the Company, Platform assistance.

2. Variabel Keputusan Pembelian (Y) Dalam penelitian ini variabel terikat yang ditetapkan adalah keputusan berkunjung wisatawan yang meliputi informasi dan rekomendasi yang diterima wisatawan melalui media social. 
Tabel 3. Operasional Variabel Penelitian

\begin{tabular}{|c|c|c|c|c|}
\hline Variabel & Indikator & & Item & Pengukuran \\
\hline \multirow{4}{*}{ 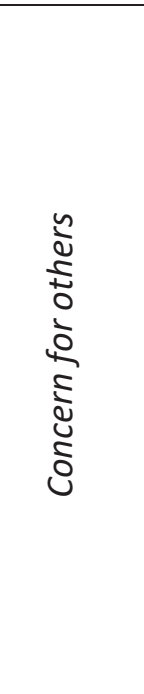 } & \multirow{2}{*}{ 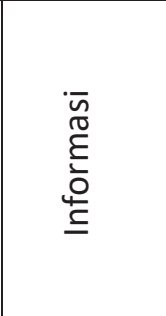 } & & $\begin{array}{l}\text { Melalui media sosial/online, saya terbantu } \\
\text { untuk mendapatkan informasi mengenai } \\
\text { pilihan produk (paket wisata) di } 3 \text { Gili Matra. }\end{array}$ & \multirow[t]{4}{*}{$\begin{array}{c}\text { Skala } \\
\text { Ordinal }\end{array}$} \\
\hline & & 2 & $\begin{array}{l}\text { Melalui media sosial/online, } \\
\text { mendapatkan informasi } \\
\text { pelayanan di } 3 \text { Gili Matra. }\end{array}$ & \\
\hline & \multirow{2}{*}{$\begin{array}{l}\bar{n} \\
\frac{0}{0} \\
\frac{c}{d} \\
\frac{\varepsilon}{0} \\
\frac{u}{d} \\
\text { r }\end{array}$} & 3 & $\begin{array}{l}\text { Melalui media sosial/online, saya dapat } \\
\text { merasakan kepedulian orang lain saat } \\
\text { merekomendasikan user untuk berkunjung ke } \\
3 \text { Gili Matra. }\end{array}$ & \\
\hline & & 4 & $\begin{array}{l}\text { Melalui media sosial/online, saya } \\
\text { mendapatkan rekomendasi yang berkaitan } \\
\text { dengan } 3 \text { Gili Matra. }\end{array}$ & \\
\hline \multirow{4}{*}{ 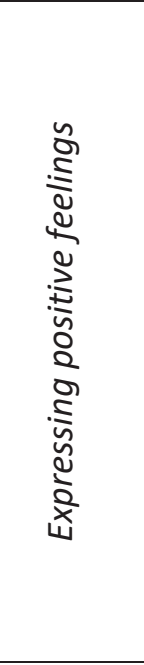 } & \multirow{2}{*}{ 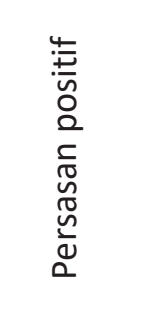 } & 1 & $\begin{array}{l}\text { Melalui media sosial/online, saya } \\
\text { mendapatkan informasi mengenai daya tarik di } \\
3 \text { Gili Matra. }\end{array}$ & \multirow[t]{4}{*}{$\begin{array}{c}\text { Skala } \\
\text { Ordinal }\end{array}$} \\
\hline & & 2 & $\begin{array}{l}\text { Melalui media sosial/online, saya dapat } \\
\text { merasakan kesenangan orang lain saat } \\
\text { ataupun setelah mengunjungi } 3 \text { Gili Matra. }\end{array}$ & \\
\hline & \multirow{2}{*}{ 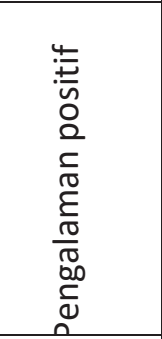 } & 3 & $\begin{array}{l}\text { Melalui media sosial/online, saya } \\
\text { mendapatkan informasi bahwa } 3 \text { Gili Matra } \\
\text { merupakan pilihan yang tepat untuk liburan. }\end{array}$ & \\
\hline & & 4 & $\begin{array}{l}\text { Melalui media sosial/online, saya } \\
\text { mendapatkan informasi mengenai pengalaman } \\
\text { positif orang lain di } 3 \text { Gili Matra. }\end{array}$ & \\
\hline \multirow{4}{*}{ 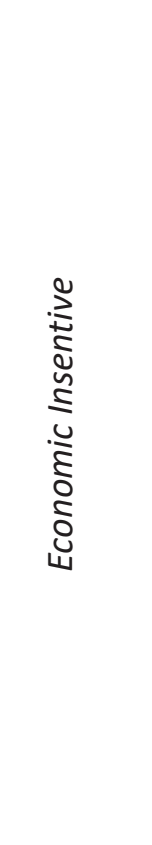 } & \multirow{2}{*}{ 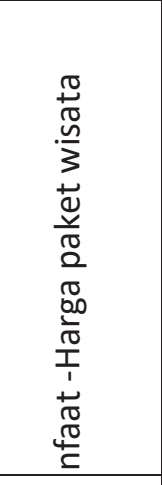 } & 1 & $\begin{array}{l}\text { Melalui media sosial/online, saya } \\
\text { mendapatkan informasi mengenai harga-harga } \\
\text { paket wisata di } 3 \text { Gili Matra sehingga saya } \\
\text { dapat menentukan paket yang sesuai dengan } \\
\text { kebutuhan saya (misalnya diving, tempat } \\
\text { istirahat dan santai) }\end{array}$ & \multirow[t]{4}{*}{$\begin{array}{l}\text { Skala } \\
\text { Ordinal }\end{array}$} \\
\hline & & 2 & $\begin{array}{l}\text { Melalui media sosial/online, saya } \\
\text { mendapatkan informasi tanpa harus datang } \\
\text { langsung ke } 3 \text { Gili Matra. }\end{array}$ & \\
\hline & \multirow{2}{*}{ 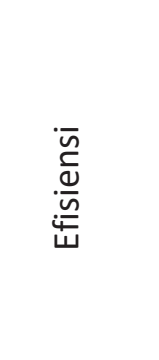 } & 3 & $\begin{array}{l}\text { Melalui media sosial/online, saya dapat } \\
\text { menanyakan berbagai hal tanpa mengeluarkan } \\
\text { banyak biaya (pulsa, transportasi). }\end{array}$ & \\
\hline & & 4 & $\begin{array}{l}\text { Melalui media sosial/online, saya dapat } \\
\text { melakukan pemesanan paket wisata tanpa } \\
\text { harus mendatangi lokasi ataupun telpon, } \\
\text { sehingga biaya lebih hemat. }\end{array}$ & \\
\hline
\end{tabular}




\begin{tabular}{|c|c|c|c|c|}
\hline \multirow{4}{*}{ 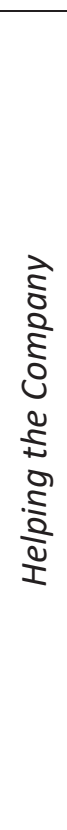 } & \multirow{2}{*}{ 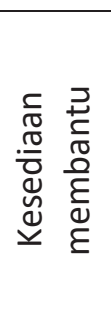 } & 1 & $\begin{array}{l}\text { Melalui media sosial/online, saya dapat } \\
\text { merasakan kesediaan orang lain dalam } \\
\text { membantu publikasi tentang } 3 \text { Gili Matra }\end{array}$ & \multirow[t]{4}{*}{$\begin{array}{c}\text { Skala } \\
\text { Ordinal }\end{array}$} \\
\hline & & 2 & $\begin{array}{l}\text { Melalui media sosial/online, saya dapat } \\
\text { merasakan orang lain menginginkan } 3 \text { Gili } \\
\text { Matra semakin berkembang dan terkenal. }\end{array}$ & \\
\hline & \multirow{2}{*}{ 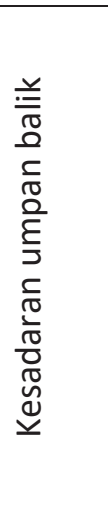 } & 3 & $\begin{array}{l}\text { Melalui media sosial/online, saya dapat } \\
\text { merasakan kesadaran orang lain akan potensi } \\
\text { wisata di } 3 \text { Gili Matra sehingga timbul pula } \\
\text { kesadaran untuk menjaga kelestarian daya } \\
\text { tarik wisata } 3 \text { Gili Matra. }\end{array}$ & \\
\hline & & 4 & $\begin{array}{l}\text { Melaluimedia } \\
\text { sosial/online,pengeloladapatmemantau kritik } \\
\text { dan saran yang disampaikan user sehingga } \\
\text { dapat dijadikan tolok ukur untuk meningkatkan } \\
\text { pelayanan. }\end{array}$ & \\
\hline \multirow{4}{*}{ 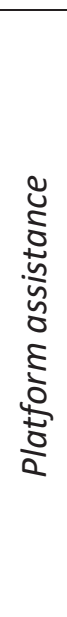 } & \multirow{2}{*}{ 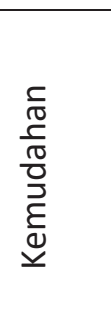 } & 1 & $\begin{array}{l}\text { Media sosial/online mempermudah eWOM } \\
\text { (komunikasi dari mulut ke mulut) mengenai } 3 \\
\text { Gili Matra. }\end{array}$ & \multirow[t]{4}{*}{$\begin{array}{l}\text { Skala } \\
\text { Ordinal }\end{array}$} \\
\hline & & 2 & $\begin{array}{l}\text { Saya dapat merasakan bahwa media } \\
\text { sosial/online adalah alat yang efektif } \\
\text { membantu proses promosi } 3 \text { Gili Matra. }\end{array}$ & \\
\hline & \multirow{2}{*}{ 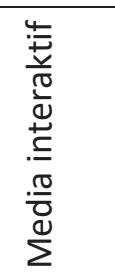 } & 3 & $\begin{array}{l}\text { Saya merasa bahwa media sosial/online dapat } \\
\text { menjadi media untuk berinteraksi antara } \\
\text { pengelola dan wisatawan. }\end{array}$ & \\
\hline & & 4 & $\begin{array}{l}\text { media sosial/online dapat menjadi alat untuk } \\
\text { bertukarinformasi antar wisatawan. }\end{array}$ & \\
\hline \multirow{5}{*}{ 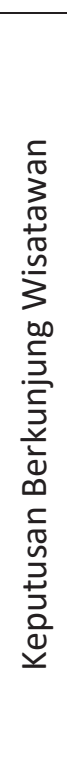 } & \multirow{2}{*}{ 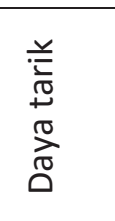 } & 1 & $\begin{array}{l}\text { Saya mengatahui } 3 \text { Gili Matra beserta berbagai } \\
\text { potensi yang ada. }\end{array}$ & \multirow[t]{5}{*}{$\begin{array}{c}\text { Skala } \\
\text { Ordinal }\end{array}$} \\
\hline & & 2 & $\begin{array}{l}\text { Saya merasa puas dengan pelayanan dan } \\
\text { fasilitas yang ada di } 3 \text { Gili Matra }\end{array}$ & \\
\hline & \multirow{3}{*}{ 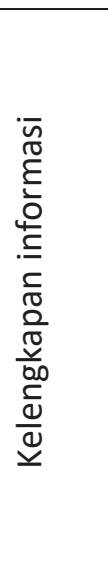 } & 3 & $\begin{array}{l}\text { Melalui media sosial/online saya mendapatkan } \\
\text { beragam informasi mengenai } 3 \text { Gili Matra dan } \\
\text { membandingkan dengan destinasi wisata } \\
\text { serupa sebagai alternatif untuk dikunjungi. }\end{array}$ & \\
\hline & & 4 & $\begin{array}{llr}\text { Setelah mengetahui informasi anda } \\
\text { memutuskan untuk berkunjung ke } 3 \text { Gili Matra. }\end{array}$ & \\
\hline & & 5 & $\begin{array}{l}\text { Setelah mengetahui } 3 \text { Gili Matra, saya } \\
\text { berkeinginan untukmencari } \\
\text { informasi lebih banyak. }\end{array}$ & \\
\hline
\end{tabular}




\section{Uji Validitas dan Reliabilitas}

\section{UjiValiditas}

Instrumen utama yang digunakan dalam penelitian ini adalah daftar pertanyaan yang disebarkan kepada responden. Instrumen yang dibuat sebelum disebarkan kepada responden yang menjadi sampel penelitian harus diuji kevalidannya dan kereliabelannya melalui analisis faktor, agar daftar pertanyaan yang dibuat tersebut benar-benar mampu menguak data sehingga mampu menjawab permasalahan hingga tujuan penelitian tercapai.

Uji validitas dimaksudkan untuk memastikan seberapa baik suatu instrumen mengukur konsep yang seharusnya diukur. Instrumen yang valid berarti instrumen tersebut dapat digunakan untuk mengukur secara tepaf. dan benar. Mempergunakan instrumen penelitian yang memiliki validitas yang tinggi, hasil penelitian mampu menjelaskan masalah penelitian sesuai dengan keadaan atau kejadian yang sebenarnya dengan signifikansi dibawah 0,05 dan KaiserMeyer-Olkin (KMO), Anti Image, dan Factor Loading > 0.5 dinyatakan valid dan sampel bisa di analisis lebih lanjut (Sekaran, 2006:311).

2. Uji Reliabilitas

Uji reliabilitas adalah tingkat ketepatan, ketelitian atau keakuratan sebuah instrumen. Instrumen yang sudah dapat dipercaya atau reliabel akan menghasilkan data yang dapat dipercaya pula (Arikunto, 2010:146). Suatu varibel dikatakan reliabeil. jika memberikan nilai alpha cronbach $(\alpha)>$ 0.60 dengan bantuan SPSS17.0.

\section{Teknik Analisis Data}

1. Analisis Kualitatif

Metode analisis kualiatif menggunakan kuesioner yang didalamnya memuat pertanyaan-pertanyaan terbuka sehingga data yang dihasilkan lebih kaya, manusiawi, tajam dan seringkali lebih membuka wawasan Sugiyono (2010:9).

2. Analisis Kuantitatif

Analisis kuantitatif adalah riset yang cara pengolahan datanya dihitung menggunakan analisis sistematis. Penelitian ini menggunakan uji regresi linier berganda.Uji regresi linier berganda digunakan untuk memeriksa kuatnya hubungan antara variabel bebas dan variabel terikat.

Menurut Sugiyono (2010:8) uji regresi linier berganda dapat dilihat dalam persamaan berikut:

\section{$Y=a+b_{1} x_{1}+b_{2} x_{2}+b_{3} x_{3}+b_{4} x_{4}+b_{5} x_{5}+e$}

Keterangan :

$Y=$ Variabel terikat yaitu keputusanpembelian

$a=$ Konstanta

$b_{1}-b_{4}=$ Koefisien regresi variabelbebas

$X_{1}=$ Concern for others

$X_{2}=$ Expressing positive feelings

$X_{3}=$ Economic Insentive

$X_{4}=$ Helping the Company

$X_{5}=$ Platform assistance

$e=$ Standarerror

Teknik Analisis Data

Uji F (Uji Simultan)

Menururt Ferdinand (2014), Uji $F$ atau uji kelayakan model dilakukan untuk melihat apakah model yang dianalisis memiliki tingkat kelayakan model yang tinggi yaitu variabelvaribel yang digunakan model mampu untuk menjelaskan fenomena yang dianalisis.

Uji ini digunakan untuk mengetahui apakah variabel independen yaituConcern for others (X1), Expressing positive feelings (X2), Economic Insentive (X3), Helping the Company (X4), Platform assistance (X5), layak menjelaskan variabel dependen yaitu Keputusan Berkunjung Wisatawan (Y) pada tingkat kepercayaan $95 \%$ atau $\alpha=5 \%$. Hasil uji $\mathrm{F}$ dapat ditemui pada tabel ANOVA (Analysis of Variance) dari output SPSS.

\section{Pengujian Hipotesis (Uji t)}

Uji ini digunakan untuk mengetahui apakah dalam model regresi variabel independen yaitu Concern for others (X1), Expressing positive feelings (X2), Economic Insentive (X3), Helping the Company (X4), Platform assistance (X5), secara parsial berpengaruh terhadap variabel dependen yaitu Keputusan Berkunjung Wisatawan (Y) pada tingkat kepercayaan $95 \%$ atau $\alpha=5 \%$. Dengan hipotesis:

1. Bila nilai signifikan ( $P$ value) $<0,05$ maka Ho ditolak dan menerima Ha yang berarti ada pengaruh antara variabel bebas dan variabel terikat.

2. Bila nilai signifikan $(P$ value $)>0,05$ maka 
Ho diterima dan menolak Ha yang berarti tidak ada pengaruh antara variabel bebas dan variabel terikat.

\section{Uji Koefisien Determinasi}

Koefisien Determinasi (Adjusted $\mathrm{R}^{2}$ ) intinya digunakan untuk mengukur seberapa jauh kemampuan dalam menerangkan variasi. Nilai koefisien determinasi diantara nol dan satu. Nilai Adjusted $R^{2}$ yang kecil berarti kemampuan variabel-variabel independen dalam menjelaskan variasi variabel dependen cukup terbatas. Nilai yang mendekati satu berarti dibutuhkan untuk memprediksi variasi variabel dependen. Secara umum koefisien determinasi untuk data silang (cross section) relatif rendah karena adanya variasi yg besar.

\section{ANALISIS DAN PEMBAHASAN}

\section{Analisis Data}

\section{Analisis Regresi}

Analisis regresi yang digunakan dalam penelitian ini adalah variabel (dependen) yang diwakili oleh Keputusan Berkunjung Wisatawan sedangkan variabel (independen) yang diwakili oleh Electronic Word Of Mouth yang terdiri dari lima dimensi yaitu : Concern for others, Expressing positive feelings, Economics Insentive, Helping the Company, Platform assistance.

Tabel 4. Hasil olahan regresi dengan SPSS

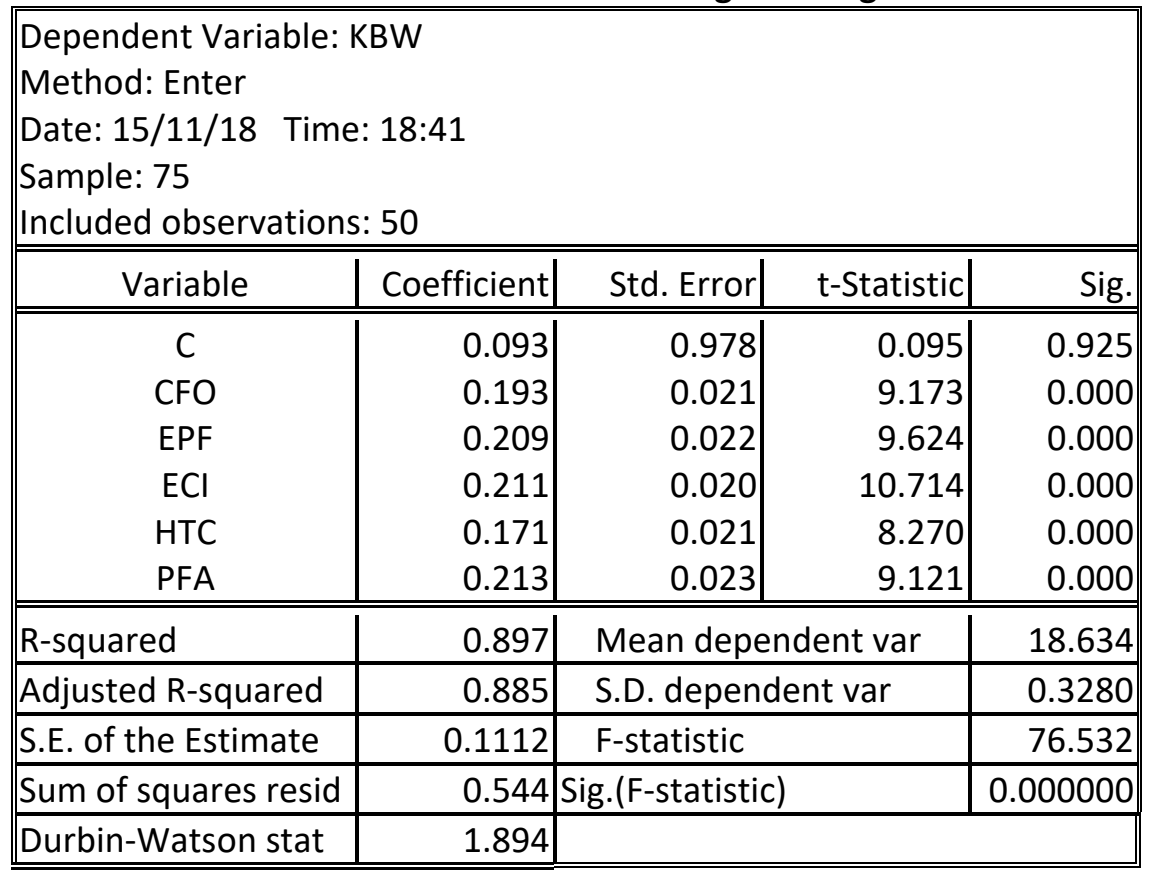

Model persamaan regresi berganda yang dibentuk adalah ;

$$
\begin{aligned}
\mathrm{KBW}= & \beta_{0}+\beta_{1} \mathrm{CFO}+\beta_{2} \mathrm{EPF}+\beta_{3} \mathrm{ECl}+\beta_{4} \mathrm{HTC}+ \\
& \beta_{5} \mathrm{PFA}+\mathrm{e} \\
\mathrm{KBW}= & 0.093+0.193 \mathrm{CFO}+0.209 \mathrm{EPF}+0.211 \mathrm{ECl} \\
& +0.171 \mathrm{HTC}+0.213 \mathrm{PFA}
\end{aligned}
$$

\section{Uji F (Uji Simultan)}

Menururt Ferdinand (2014), Uji F atau uji kelayakan model dilakukan untuk melihat apakah model yang dianalisis memiliki tingkat kelayakan model yang tinggi yaitu variabel-varibel yang digunakan model mampu untuk menjelaskan fenomena yang dianalisis.
Dari uji $\mathrm{F}$ diatas dengan nilai $\mathrm{F}$ hitung sebesar 76,532 lebih besar dari $F$ tabel sebesar 2,43, dengan tingkat signifikansinya sebesar 0,000 , dapat ditarik kesimpulan bahwa seluruh variabel independen (Dimensi Electronic Word of Mouth) Layak untuk menjelaskan variabel dependen yang dianalisis yaitu Keputusan Berkunjung Wisatawan di Tiga Gili Matra Kabupaten Lombok Utara (KLU).

\section{Uji t (Uji Parsial)}

Uji t mengukur seberapa jauh pengaruh satu variabel penjelas secara individu dalam menerangkan variasi variabel terikat. Kriteria uji t sebagai berikut; 
"Jika t hitung > dari t tabel maka uji tersebut signifikan/ada pengaruh (Ha diterima) dan jika t hitung < dari t tabel maka uji tersebut tidak signifikan/tidak ada pengaruh (Ha ditolak)".

Tabel 5. Ringkasan Hasil Uji Koefisien Regresi

\begin{tabular}{|l|l|r|l|l|l|}
\hline No & Variabel & Nilai t hitung & $\begin{array}{l}\text { Nilai t tabel } \\
\mathrm{dg} \alpha=5 \%\end{array}$ & $\begin{array}{l}\text { Nilai Signifikan } \\
(\text { Sig, }) \text { dgn } \alpha=5 \%\end{array}$ & Keterangan \\
\hline 1 & CFO & 9,173 & 1,67 & 0,000 & Signifikan \\
\hline 2 & EPF & 9,624 & 1,67 & 0,000 & Signifikan \\
\hline 3 & ECI & 10,714 & 1,67 & 0,000 & Signifikan \\
\hline 4 & HTC & 8,270 & 1,67 & 0,000 & Signifikan \\
\hline 5 & PFA & 9,121 & 1,67 & 0,000 & Signifikan \\
\hline
\end{tabular}

Sumber : Data (diolah)

Dari tabel 4.5 diatas terlihat bahwa;

1. Nilai t hitung $(9,173)$ dari variabel Concern for others lebih besar dari t tabel $(1,67)$, dengan tingkat signifikansi $0,000<\alpha=$ 0,05, maka Ho diterima dan Ha ditolak. hal ini berarti Concern for others memiliki pengaruh yang signifikan terhadap Keputusan Berkunjung Wisatawan di Tiga Gili Matra Kabupaten Lombok Utara (KLU)

2. Nilai $t$ hitung $(9,624)$ dari variabel Expressing positive feelings lebih besar dari ttabel $(1,67)$, dengan tingkat signifikansi $0,000<\alpha=0,05$, maka Ho diterima dan $\mathrm{Ha}$ ditolak. hal ini berarti Expressing positive feelings memiliki pengaruh yang signifikan terhadap Keputusan Berkunjung Wisatawan di Tiga Gili Matra Kabupaten Lombok Utara (KLU))

3. Nilai $t$ hitung $(10,714)$ dari variabel Economics Insentive lebih besar dari $\mathrm{t}$ tabel $(1,67)$, dengan tingkat signifikansi $0,000<\alpha=0,05$, maka Ho di diterima dan $\mathrm{Ha}$ ditolak. hal ini berarti Variabel Economics Insentive memiliki pengaruh yang signifikan terhadap Keputusan Berkunjung Wisatawan di Tiga Gili Matra Kabupaten Lombok Utara (KLU)

4. Nilai t hitung $(8,270)$ dari variabel Helping the Company lebih besar dari $\mathrm{t}$ tabel $(1,67)$, dengan tingkat signifikansi $0,000<$ $\alpha=0,05$, maka Ho diterima dan $\mathrm{Ha}$ ditolak. hal ini berarti Variabel Helping the Company memiliki pengaruh yang signifikan terhadap Keputusan Berkunjung Wisatawan di Tiga Gili Matra Kabupaten Lombok Utara (KLU)

5. Nilai $t$ hitung $(9,121)$ dari variabel Platform assistance lebih besar dari t tabel $(1,67)$, dengan tingkat signifikansi $0,000<\alpha=0,05$, maka Ho diterima dan Ha ditolak. hal ini berarti Variabel Platform assistance memiliki pengaruh yang signifikan terhadap Keputusan Berkunjung Wisatawan di Tiga Gili Matra Kabupaten Lombok Utara (KLU)

\section{Uji $\mathbf{R}^{2}$ (Uji Koefisien Determinasi)}

Uji ini mengukur seberapa jauh kemampuan model dalam menjelaskan variasi variabel terikat, dimana dari tabel 4.1 terlihat bahwa nilai $R^{2}$ adalah 0,897 , maka nilai $R^{2}$ nya mendekati 1 yang berarti variabel-variabel independen memberikan hampir seluruh informasi yang dibutuhkan untuk memprediksi variasi variabel terikatnya atau 89 \% variasi variabel Keputusan Berkunjung Wisatawan di Tiga Gili Matra Kabupaten Lombok Utara (KLU)dijelaskan oleh variasi variabel Dimensi Electronic Word of Mouthsedangkan $11 \%$ dipengaruhi oleh variabel lainnya.

\section{Pembahasan}

Dari analisis regresi berganda dengan menggunakan variabel-variabel independen E-Wom (Concern for Others, Expressing Positive Feelings, Economic Insentive, Helping The Company, Platform Assistance) dan variabel dependen yang digunakan adalah Keputusan Berkunjung Wisatawan(KBW), maka dimensi E-Womtersebut yang mempengaruhi keputusan berkunjung wisatawan adalah:

1. Variabel Concern For Others, dengan nilai t hitung $(9,173)$ dari variabel Concern For Others lebih besar dari t tabel $(1,67)$, dengan tingkat signifikansi $0,000<\alpha=$ 0,05, maka Ho di diterima dan $\mathrm{Ha}$ ditolak.Hal ini berarti Concern For Others 
memiliki pengaruh yang positif dan signifikan terhadap Keputusan Berkunjung Wisatawan di Tiga Gili Kabupaten Lombok Utara (KLU)

2. Variabel Expressing Positive Feelings, dengan nilai t hitung $(9,624)$ dari variabel Expressing Positive Feelings lebih besar dari $t$ tabel $(1,67)$, dengan tingkat signifikansi $0,000<\alpha=0,05$, maka $\mathrm{Ho}$ di diterima dan $\mathrm{Ha}$ ditolakHal ini berarti Expressing Positive Feelingsmemiliki pengaruh yang positif dan signifikan terhadap Keputusan Berkunjung Wisatawan di Tiga Gili Kabupaten Lombok Utara (KLU)

3. Variabel Economic Insentive, dengan nilai t hitung $(10,714)$ dari variabel Economic Insentive lebih besar dari $\mathrm{t}$ tabel $(1,67)$, dengan tingkat signifikansi $0,000<\alpha=$ 0,05, maka Ho di diterima dan $\mathrm{Ha}$ ditolakHal ini berarti Economic Insentive memiliki pengaruh yang positif dan signifikan terhadap Keputusan Berkunjung Wisatawan di Tiga Gili Kabupaten Lombok Utara (KLU)

4. Variabel Helping The Company, dengan nilai t hitung $(8,270)$ dari variabel Helping The Company lebih besar dari $t$ tabel $(1,67)$, dengan tingkat signifikansi $0,000<\alpha$ $=0,05$, maka Ho di diterima dan Ha ditolak. Hal ini berarti Helping The Company memiliki pengaruh yang positif dan signifikan terhadap Keputusan Berkunjung Wisatawan di Tiga Gili Kabupaten Lombok Utara (KLU)

5. Variabel Platform Assistance, dengan nilai t hitung $(9,121)$ dari variabel Platform Assistance lebih besar dari t tabel $(1,67)$, dengan tingkat signifikansi $0,000<\alpha=$ 0,05, maka Ho di diterima dan $\mathrm{Ha}$ ditolak. Hal ini berarti Platform Assistance memiliki pengaruh yang positif dan signifikan terhadap Keputusan Berkunjung Wisatawan di Tiga Gili Kabupaten Lombok Utara (KLU)

Dari analisis Regresi berganda untuk model dengan menggunakan variabel-variabel independen E-Wom (Concern for Others, Expressing Positive Feelings, Economic Insentive, Helping The Company, Platform Assistance)dan variabel dependen yang digunakan adalah Keputusan Berkunjung
Wisatawan(KBW), maka variabel yang paling mempengaruhi Keputusan Berkunjung Wisatawan adalah variabel Economic Insentive (ECI), dimana hubungan ini terlihat dari uji $t$ dengan nilai $t$ hitunglebih besar dibandingkan $t$ hitung variabel independen lainnya yaitu 10,714 dan tingkat signifikansi 0,000

Artinya Pemerintah Daerah KLU khususnya Dinas Kebudayaan dan Pariwisata harus benar-benar menjaga dan memperhatikan variabel Economic Insentive (Manfaat Ekonomi) karena variabel tersebuttelah ditunjuk sebagai pendorong penting dari perilaku manusia secara umum dan dianggap oleh penerima sebagai tanda penghargaan. Selain itu wisatawan yang berkunjung juga akan merasa dilibatkan dan pada akhirnya ada keterikatan yang timbulsehingga ingin selalu berwisata khususnya ke Tiga Gili di Kabupaten Lombok Utara (KLU).

\section{KESIMPULAN DAN SARAN}

\section{Kesimpulan}

1. Variabel independen (Concen For Others, Expressing Positive Feelings, Economic Insentive, Helping The Company, Platform Assistance) layak untuk menjelaskan variabel dependen (Keputusan Berkunjung Wisatawan) yang dianalisis. Dengan nilai $F_{\text {hitung }}>F_{\text {tabel }}(76,532>2,431)$.

2. Variabel Concern For Othersberpengaruh positif dan signifikan terhadap Keputusan Berkunjung Wisatawan dengan nilai $t_{\text {hitung }}$ sebesar 9,173 lebih besar dari tabel sebesar $1,67(9,173>1,67) \quad$ dan dengan nilai signifikansi 0,000.

3. Variabel Expressing Positive Feelingsberpengaruh positif dan signifikan terhadap Keputusan Berkunjung Wisatawan dengan nilai $t_{\text {hitung }}$ sebesar 9,624 lebih besar dari $t_{\text {tabel }}$ sebesar 1,67 $(9,624>1,67)$ dan dengan nilai signifikansi 0,000 .

4. Variabel Economic Insentiveberpengaruh positif dan signifikan terhadap Keputusan Berkunjung Wisatawan dengan nilai thitung sebesar 10,714 lebih besar dari $t_{\text {tabel }}$ sebesar $1,67(10,714>1,67)$ dan dengan nilai signifikansi 0,000 . 
5. Variabel Helping The Company berpengaruh positif dan signifikan terhadap Keputusan Berkunjung Wisatawan dengan nilai $t_{\text {hitung }}$ sebesar 8,270 lebih besar dari $t_{\text {tabel }}$ sebesar 1,67 $(8,270>1,67)$ dan dengan nilai signifikansi 0,000 .

6. Variabel Platform Assistanceberpengaruh positif dan signifikan terhadap Keputusan Berkunjung Wisatawan dengan nilai $t_{\text {hitung }}$ sebesar 9,121 lebih besar dari tabel sebesar $1,67 \quad(9,121>1,67) \quad$ dan dengan nilai signifikansi 0,000 .

\section{Saran}

1. Penelitian terhadap Dimensi E-Womdalam mempengaruhi Keputusan Berkunjung Wisatawan di Tiga Gili Kabupaten Lombok Utara (KLU) masih kurang sehingga diperlukan adanya penambahan responden dan variabel di luar E-Wom . Bagi peneliti selanjutnya, selain jumlah responden agar aspek-aspek lain di luar Dimensi E-Wom yang paling mempengaruhi Keputusan Berkunjung Wisatawan di Tiga Gili Kabupaten Lombok Utara (KLU) yang belum tercantum dalam penelitian ini agar dimasukkan sebagai variabel penelitian untuk menghasilkan penelitian yang lebih komprehensif.

2. Perlu adanya tindak lanjut dari pemerintah Kabupaten Lombok Utara (KLU) maupun Pemprov NTB dalam memberikan apresiasi kepada wisatawan yang berkunjung karena akan mempengaruhi keputusan wisatawan dalam berkunjung, sehingga masyarakat KLU pada umumnyaakan lebih banyak mendapatkan manfaat.

\section{DAFTAR PUSTAKA}

Anonin.Undang-Undang No. 10 Tahun 2009 Tentang Kepariwisataan

Ali Ibrahim, Mohammed.The Determinants of International Tourism Demand for Egypt: Panel Data Evidence.European Journal of Economics, Finance and Administrative Sciences ISSN 1450-2275 Issue 30 (2011)

Bagus, I Gusti, dkk. 2012. Metodologi Penelitian Pariwisata dan Perhotelan. CV Andi Offset: Yogyakarta.

Beverley A. Spark et,al. The Impact of Online Reviews on Hotel Booking Intention and Perception of Trust. Tourism Management Journal, 2011, 32, 1310-1323

Emilia Gabroveanu et,al. Analysis of Main Economic Factors Influence on Romanian Tourists Number Accommodated in Romania, using Anova Method.Theoretical and Applied Economics Journal, 2010

Ghozali.2006.Analisis Multivariate Lanjutan Dengan ProgramSPSS. Badan Penerbit UNDIP. Semarang Marpaung, Happy. 2002. Pengetahuan Kepariwisataan. Alpabeta Bandung.

Pitana, dkk. 2009. Pengantar Ilmu Pariwisata.CV Andi Offset: Yogyakarta

Pendit, Nyoman. 1999. Ilmu Pariwisata Sebuah Pengantar Perdana. PT.Pradnya Paramita.Jakarta

Qiang Ye et,al. The Influence user-generated content on Traveler Behaviour: An Empirical Investigation on the Effects of e word of mouth to hotel online bookings. Computer in Human Behaviour Journal,2011, 27, 634-639

Raymond Y.C. Tse. Estimating the impact of economic factorson tourism: evidence from Hong Kong.Tourism Economics Journal, 2001, 7 (3), 277-293

Suwantoro, Gamal, 1997.Dasar-dasar Pariwisata. ANDY. Yogyakarta 
Masrun, Akłmad Jufri, Titi Yuniarti/Model Pemberdayaan VKM... $\mid 89$

Spillane. James. 1994. Pariwisata Indonesia : Siasat Ekonomi dan Rekayasa Kebudayaan.Kanisius.Yogyakarta.

Sharpley. 1994. Tourism, Tourism and Socciety. Huntingdom: ELM Publication

Soekadijo, R. G, 1997. Anatomi Pariwisata :Memahami Pariwisata Sebagai Sistem Linkage. Gramedia Pustaka Utama. Jakarta. 